\title{
Phosphorus plant removal from European agricultural land
}

\author{
Panos Panagos $^{1}$ (D) Anna Muntwyler ${ }^{1} \cdot$ Leonidas Liakos $^{1} \cdot$ Pasquale Borrelli $^{2} \cdot$ Irene Biavetti $^{1} \cdot$ Mariia Bogonos $^{3}$. \\ Emanuele Lugato ${ }^{1}$
}

Received: 8 November 2021 / Revised: 21 December 2021 / Accepted: 5 January 2022 / Published online: 5 February 2022

(c) The Author(s) 2022

\begin{abstract}
Phosphorus (P) is an important nutrient for all plant growth and it has become a critical and often imbalanced element in modern agriculture. A proper crop fertilization is crucial for production, farmer profits, and also for ensuring sustainable agriculture. The European Commission has published the Farm to Fork (F2F) Strategy in May 2020, in which the reduction of the use of fertilizers by at least $20 \%$ is among one of the main objectives. Therefore, it is important to look for the optimal use of $\mathrm{P}$ in order to reduce its pollution effects but also ensure future agricultural production and food security. It is essential to estimate the $\mathrm{P}$ budget with the best available data at the highest possible spatial resolution. In this study, we focused on estimating the P removal from soils by crop harvest and removal of crop residues. Specifically, we attempted to estimate the $P$ removal by taking into account the production area and productivity rates of 37 crops for 220 regions in the European Union (EU) and the UK. To estimate the P removal by crops, we included the P concentrations in plant tissues (\%), the crop humidity rates, the crop residues production, and the removal rates of the crop residues. The total $\mathrm{P}$ removal was about 2.55 million tonnes (Mt) $( \pm 0.23 \mathrm{Mt}$ ), with crop harvesting having the larger contribution (ca. 94\%) compared to the crop residues removal. A Monte-Carlo analysis estimated a $\pm 9 \%$ uncertainty. In addition, we performed a projection of $\mathrm{P}$ removal from agricultural fields in 2030. By providing this picture, we aim to improve the current $\mathrm{P}$ balances in the EU and explore the feasibility of F2F objectives.
\end{abstract}

Keywords Phosphorus budget $\cdot$ Plant uptake $\cdot$ Farm to Fork $\cdot$ Nutrients $\cdot$ Crop production $\cdot$ Phosphorus removal $\cdot$ Food security

\section{Introduction}

Nitrogen $(\mathrm{N})$, phosphorus $(\mathrm{P})$, and potassium $(\mathrm{K})$ are essential nutrients for plant growth. They are uptaken by the crops from soil and have to be replenished by mineral or organic fertilisers to meet crop demand (Schoumans et al. 2015). Without the fertilization of those nutrients, the agricultural crop production would be limited and soil mined.

The food production in Europe is dependent on imported $P$ fertilizers, but is often inefficient and its losses to the

Panos Panagos

panos.panagos@ec.europa.eu

1 European Commission, Joint Research Centre (JRC), Ispra, Italy

2 Dipartimento di Scienze della Terra e dell'Ambiente, Università degli Studi di Pavia, Pavia, Italy

3 European Commission, Joint Research Centre (JRC), Seville, Spain environment are high (Ott and Rechberger 2012). The farmers in the EU were using more P fertilizers than the crop needs until the first decade of 21 st century (Schouwmans et al. 2015). Western Europe was the largest consumer of $P$ fertilizers per unit of agricultural land during the period of 1961-2012 (Schouwmans et al. 2015). However, there has been a decline in $\mathrm{P}$ fertilizer use rate in Europe during the last years compared to the 1980's (Lu and Tian 2017). A P surplus in agricultural soils can lead to environmental pollution like the eutrophication of freshwaters (Dupas et al. 2015). Therefore, it is important to reduce excessive use of mineral and organic fertilizers while ensuring enough food production.

However, depending on soil properties ( $\mathrm{pH}$, soil organic carbon, etc.) and the weathering processes, the added $\mathrm{P}$ undergoes various reactions (e.g. precipitation, adsorption), transforming it into increasingly less soluble forms that reduce its availability to plants (Roberts and Johnston, 2015). This sorbed $P$ fraction is subsequently vulnerable to be lost from the soil due to soil erosion by water (Carpenter and Bennett 2011) as it is transported by sediments. 
The European Commission Joint Research Centre (JRC) is managing the largest pan-European topsoil survey named Land Use/Cover Area frame Survey (LUCAS) by collecting more than 20,000 samples every three years and analysing them for physical and chemical properties (Orgiazzi et al. 2018). Soil nutrients are among the analysed parameters of LUCAS allowing to assess their spatial distribution in European soils (Ballabio et al. 2019). Therefore, the LUCAS topsoil surveys and the modelled assessments allow to better monitor the status and trends of soil nutrients and identify hotspots in the EU.

$\mathrm{P}$ is uptaken by plants and is removed from soils when crops are harvested or grass is grazed (OECD 2007). Understanding and quantifying the phosphorus needs in agriculture at large scales (e.g. country, continent) is important for better management of fertilization, phosphate market requests and identification of the potential risk of eutrophication (Carpenter 2008).

Therefore, the objectives of this study are to (a) investigate the main outputs of $\mathrm{P}$ budget in the European agricultural soils; (b) map the $\mathrm{P}$ removal both by crop harvesting and residues and (c) develop a framework to ingest statistical crop data and produce a regional (spatial explicit) $\mathrm{P}$ output dataset. Finally, we consider scenarios of nutrients reduction relevant to recent policy developments in the EU legislation, such as the F2F Strategy.

\subsection{Policy framework}

The F2F Strategy is at the heart of the EU Green Deal, aiming at making food systems fair, healthy and environmentally friendly (European Commission 2020). The F2F Strategy addresses the challenges of sustainable food systems and recognizes the inextricable links between healthy people, healthy societies and a healthy planet (European Commission 2020). One of the objectives of the F2F Strategy is to reduce the excess of nutrients (nitrogen and phosphorus) in the environment and limit the excessive use of fertilizers. The aim is to reduce nutrient losses by at least $50 \%$ while ensuring no deterioration in soil fertility (Montanarella and Panagos 2021). The strategy proposes to reduce the use of fertilizers by at least $20 \%$ by 2030 .

To reach this objective, the EU Member States will identify nutrient load reductions and apply balanced fertilization and sustainable nutrient management. Therefore, an integrated nutrient management action plan is necessary to achieve such ambitious objectives without limiting food security and soil fertility. In this policy context, it is important to investigate whether such ambitious targets will influence food security and agricultural production in the EU. Some first results show that reduced agricultural inputs (fertilizer, pesticides, land, and antimicrobials) could reduce agricultural production by $12 \%$ (Beckman et al. 2021) in the EU.

\section{Materials and methods}

\subsection{Study area}

The study area includes all agricultural lands in the EU and the UK. These cover about $41.5 \%$ of the total land area, estimated to be about 180 million hectare (Mha). About 9.3 Mha of agricultural land are set aside (agricultural land which is not cultivated for conservation purposes); therefore, the area of investigation is about 170 million ha (Fig. 1).

The fraction of the total area occupied by agricultural land is not equally distributed among European countries. For example, in Ireland, the Netherlands, and Denmark more than $3 / 4$ of total land is occupied by agriculture (Fig. 1), while this share is less than $1 / 4$ in Malta, Finland and Sweden (Fig. 1), showing substantial variations between countries (Panagos et al. 2021).

\subsection{Available phosphorus in EU agricultural soils}

Based on 20,000 samples of LUCAS topsoil survey, we modelled the spatial distribution of $\mathrm{P}$ available in EU agricultural soils (Fig. 1).

There is a high variability of $\mathrm{P}$ available in the EU agricultural topsoils with the Mediterranean basin having low availability $\left(<25 \mathrm{mg} \mathrm{P} \mathrm{kg}^{-1}\right)$, while the North-western part of the EU showing saturation $\left(>50 \mathrm{mg} \mathrm{P} \mathrm{kg}^{-1}\right)$. According to literature findings (Bai et al. 2013; Fischer et al. 2017; Sharpley et al. 2012), the critical Olsen-P for crop production could be in the range of $18-25 \mathrm{mg} \mathrm{kg}^{-1}$, the optimal level in the range of $25-50 \mathrm{mg} \mathrm{kg}^{-1}$, while saturation over $50 \mathrm{mg} \mathrm{kg}^{-1}$. Agricultural soils saturated with $\mathrm{P}\left(>50 \mathrm{mg} \mathrm{kg}^{-1}\right)$ are about $13 \%$ of the study area (Fig. 1), where farmers should apply fertilization and manure inputs with care. For the agricultural soils with a P deficit ( $28 \%$ of the study area), it is important to preserve soil fertility with $\mathrm{P}$ inputs balancing the crop uptakes and exportation.

\subsection{Empirical model for phosphorus balance}

We have developed an accounting framework through an empirical model for phosphorus balance (EMPBa), which is based on the Eq. (1):

$$
\begin{aligned}
\text { Phosphorus budget }= & \text { P_Fert }+ \text { P_Man }+ \text { P_Atm } \\
& -P \_ \text {Grain }- \text { P_Res }- \text { P_Eros }
\end{aligned}
$$

where.

- P_Fert is the input of fertilizer;

- P_Man is the input from manure application;

- P_Atm is the input from atmospheric deposition;

- P_Grain the output from crop harvesting; 


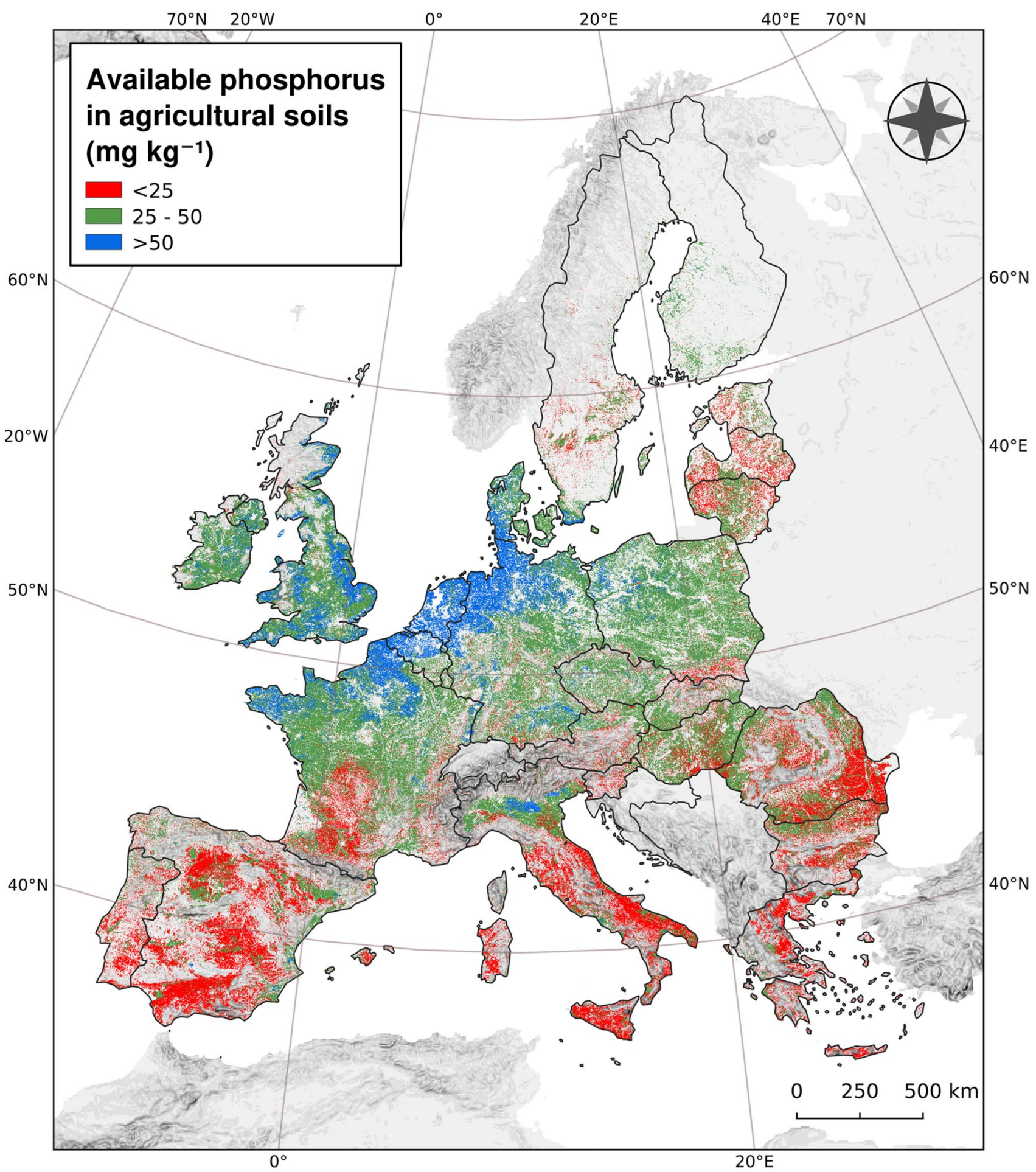

Fig. 1 Available phosphorus in agricultural soils of the EU and UK (modified from Ballabio et al. 2019)

- P_Res the output with crop residues removal;

- P_Eros the phosphorus losses due to water erosion.

The unit in Eq. (1) is in tonnes. The EMPBa takes into account the more disaggregated datasets at the EU level that may differ in scales (from a regional to country level and to continental [European]). In the current study, we illustrate the $\mathrm{P}$ outputs by crop harvesting and by residues removal. Therefore, we estimate the P_Grain and the P_Res terms of the Eq. (1) since they are the main P outputs (Smil 2000). 
The rest of the variables in Eq. (1) and the $\mathrm{P}$ balance are not addressed in this study. The $\mathrm{P}$ inputs in the Empirical Model for Phosphorus Balance (EMPBa) comes from are the fertilizer and manure inputs and the atmospheric deposition as well.

At the technical level, the EMPBa implementation is based on Free and Open Source Software (FOSS). We have used the GNU/Linux, which is hosted by the Big Data Analytics Platform (BDAP-JEODPP) of the European Commission JRC infrastructure (Soille et al. 2018). The R programming language is adopted for data analysis, harmonization, statistical computing, and graphics visualization. Mapping of research results was conducted with QGIS. As some of the results will be presented at regional scale, here we refer to the 220 EU regions which are regularly named as NUTS2 (Nomenclature of the Territorial Units for Statistics), where regional EU policies are applied (Panagos et al. 2013).

As data come from multiple sources (EUROSTAT, modelling, literature), their harmonization is an important step to make them interoperable. The results are obtained through a scripts sequence in order to achieve the reproducibility of the research. In addition to the harmonization by crop category, the spatial matching of different source datasets is necessary. As the input data are available for the most detailed level (regional level-NUTS2), data aggregation into higher hierarchical spatial statistical units (countries, continental) can be realized.

\subsection{Modelling crop P outputs with harvesting}

Phosphorus is essential for plant growth and development, especially in the early growing phases (White and Hammond 2008). $P$ is removed from soils by harvesting the biomass and mowing the pastures (MacDonald et al. 2011). Each crop has a different $P$ removal depending on $P$ tissue concentration and the fraction of biomass harvested (Ohm et al. 2017). However, values may a broad range in scientific and technical literature. Therefore, we used consistent databases and assimilated JRC products, combined with literature findings to estimate the $\mathrm{P}$ removal of crops in agricultural soils (Table 1).

Common Agricultural Policy Regional Impact Analysis (CAPRI) includes a detailed database with production statistics for 37 cropping activities in circa 220 EU regions (Panagos et al. 2021). In a first step, we calculated the regional crop production by multiplying the mean crop production rates (Cpr) with the Agricultural utilized area (AUA) per crop. In a second step, we calculated the P removal by multiplying the total production (in tonnes), the dry matter content, and $\mathrm{P}$ concentration by each specific crop.

To estimate this removal, we developed a script that combines:
- Crop type

- Crop production ( $\mathrm{t} \mathrm{ha}^{-1}$ as fresh matter) (Cpr)

- Agricultural Utilized Area (ha) (AUA)

- Humidity rate (\%) (Hum)

- $\mathrm{P}$ concentration (\%) in plant tissue as dry production (Pc)

P_CropUptake $($ tonnes $)=\mathrm{Cpr} \times \mathrm{AUA} \times(1-\mathrm{Hum}) \times \mathrm{Pc}$

P_Grain $=\sum_{n=1}^{37}$ (P_CropUptake $)$

The mean crop production rates $(\mathrm{Cpr})$ originates from the Common Agricultural Policy Regional Impact Analysis (CAPRI) model, with reference year 2016. However, the crop production rates were also compared with those from Eurostat and data from the Crop Growth Monitoring System (CGMS) used in Monitoring Agricultural Resources (MARS) (Biavetti et al. 2014). In addition, we used the Agricultural utilized area (AUA) per crop and region from CAPRI.

The humidity rates, used to convert the total production to dry matter, were retrieved from Eurostat statistics (Supplementary material Table S1). Cereals, oilseeds, dry pulses, and protein crops have a moisture content generally ranging between $10 \%$ and $14 \%$, while the plants harvested green have a high moisture content (55-80\%) (Eurostat 2020a).

It is important that farmers have a good knowledge of plant nutrient requirements in order to apply the necessary $\mathrm{P}$ fertilization. According to the literature, the $\mathrm{P}$ concentrations in well-fertilized plants approximate $0.4-1.5 \%$ of the dry matter (Broadley et al. 2004).

The $\mathrm{P}$ concentration for the different crops (Pc in Table 1) stems from a non-exhaustive literature review of field experiments (Fageria et al. 2013; Gallet et al. 2003; Rideout and Gooden 2000; Piccoli et al. 2021; Morari et al. 2008; Giardini 2002), compiled data from national research institutions (e.g. INRA) (Ehlert et al. 2009; Sauvant et al. 2004) and regional nutrient regulations and fertilizer recommendations (Palese et al. 2012; Veneto Agricoltura 2020). Most $\mathrm{P}$ concentration are derived from crops grown in Europe (Italy, France, Netherlands, and Switzerland), nevertheless, crop specific literature from the US (tobacco) and Brazil (rice, corn, soy, beans) was also included due to otherwise limited information for these crops. The crop concentration coefficients are expressed on the dry matter. Where multiple values were available, the weighted average is calculated with the number of samples serving as weights (eq. 4). 
Table 1 Phosphorus concentration of marketable crop products (based on literature reviews)

\begin{tabular}{lllll}
$\begin{array}{l}\text { P concentration (\%) } \\
\text { on dry matter yield } \\
(\mathrm{Pc})\end{array}$ & $\begin{array}{l}\text { Standard } \\
\text { deviation (SD } \\
\text { of } \mathrm{Pc})\end{array}$ & No of samples & References & Comment \\
\hline
\end{tabular}

\section{Cereals}

Soft wheat

Durum wheat

Rye and meslin

0.3881

0.3559

$0.0594^{\mathrm{a}}$

332

Barley

0.4058

0.4392

Oats

Grain maize

0.2380

0.3559

Other cereals

0.2072

Paddy rice

Oilseeds

Rape

Sunflower

Soya

0.5806

0.5842

0.58

Other oils

Other arable

Pulses

Potatoes

Sugar beet

0.1742

0.6913

0.2489

Tobacco

0.6

Other industrial crops

Other crops

Vegetables

Tomatoes

Other vegetables

\section{4}

0.4

0.4874 $0.0594^{\mathrm{a}}$

332

$0.0144^{\mathrm{a}}$

$0.071^{\mathrm{c}}$

$0.01^{\mathrm{c}}$

$0.0571^{\mathrm{b}}$

$0.0023^{\mathrm{a}}$

$0.0245^{\mathrm{a}}$

$0.0076^{\mathrm{a}}$

$0.0484^{\mathrm{a}}$

1

52

2

32

$0.0493^{\mathrm{a}}$

$0.0466^{\mathrm{a}}$

$0.0312^{\mathrm{a}}$

8

$0.104^{\mathrm{c}} \quad 190$

$0.04^{\mathrm{c}}$

Ehlert et al. (2009)

Gallet et al. (2003), Sauvant et al. (2004), Piccoli et al. (2021) and Ehlert et al. (2009)

Sauvant et al. (2004)

Sauvant et al. (2004) and Ehlert et al. (2009)

Gallet et al. (2003), Sauvant et al. (2004) and Ehlert et al. (2009)

Sauvant et al. (2004) and Ehlert et al. (2009)

Sauvant et al. (2004), Fageria et al. (2013), Piccoli et al. (2021) and Giardini (2002)

Gallet et al (2003), Sauvant Similar to wheat et al. (2004) and Ehlert et al. (2009)

Sauvant et al. (2004) and Fageria et al. (2013)

Gallet et al. (2003), Sauvant et al. (2004) and Ehlert et al. (2009)

Sauvant et al. (2004)

Gallet et al. (2003), Sauvant et al. (2004) and Fageria et al. (2013)

Sauvant et al. (2004), Ehlert et al. (2009) and Fageria et al. (2013)

Gallet et al. (2003), Sauvant et al. (2004) and Ehlert et al. (2009)

Gallet et al (2003), Ehlert et al. (2009) and Legnaro (2009)

Ehlert et al. (2009)

Rideout and Gooden (2000)

Ehlert et al. (2009)

Based on the values for cabbage, cabbage turnip, onion, broccoli, ice lettuce, spinach 
Table 1 (continued)

\begin{tabular}{|c|c|c|c|c|c|}
\hline & $\begin{array}{l}\mathrm{P} \text { concentration }(\%) \\
\text { on dry matter yield } \\
(\mathrm{Pc})\end{array}$ & $\begin{array}{l}\text { Standard } \\
\text { deviation (SD } \\
\text { of } \mathrm{Pc})\end{array}$ & No of samples & References & Comment \\
\hline Flowers & 0.2142 & $0.03^{\mathrm{c}}$ & 271 & Ehlert et al. (2009) & $\begin{array}{l}\text { Based on Anemone, Dahlia, } \\
\text { Fritillaria, Gladiolus, Hya- } \\
\text { cinth, Iris, Crocus, Lily, } \\
\text { Tulip, Tantedeschia }\end{array}$ \\
\hline $\begin{array}{l}\text { New energy crops (ligne- } \\
\text { ous) }\end{array}$ & 0.48 & & & & \\
\hline \multicolumn{6}{|l|}{ Fodder } \\
\hline Fodder maize & 0.2111 & $0.1205^{\mathrm{a}}$ & 18 & $\begin{array}{l}\text { Ehlert et al. (2009) and } \\
\text { Legnaro (2009) }\end{array}$ & \\
\hline Fodder root crops & 0.2185 & $0.042^{\mathrm{b}}$ & 19 & Ehlert et al. (2009) & Based on forage beet \\
\hline $\begin{array}{l}\text { Fodder other on arable } \\
\text { land }\end{array}$ & 0.2111 & & & $\begin{array}{l}\text { Ehlert et al. (2009) and } \\
\text { Gallet et al (2003) }\end{array}$ & $\begin{array}{l}\text { Similar to fodder maize } \\
\text { (found in Legnaro experi- } \\
\text { mental site) }\end{array}$ \\
\hline \multicolumn{6}{|l|}{ Permanent crops } \\
\hline Apples pears Peaches & 0.185 & & & Emilia et al. (2018) & \\
\hline Other fruits & 0.185 & & & & \\
\hline Citrus fruits & 0.185 & & & & \\
\hline Grapes & 0.220 & & & Veneto Agricoltura (2020) & \\
\hline Olives & 0.104 & & & Palese et al. (2012) & \\
\hline \multicolumn{6}{|l|}{ Pastures } \\
\hline Intensive & 0.3616 & NA & 152 & Gallet et al. (2003) & $\begin{array}{l}\text { We used the same SD as the } \\
\text { extensive pastures }\end{array}$ \\
\hline Extensive & 0.2613 & $0.0553^{\mathrm{a}}$ & 198 & $\begin{array}{l}\text { Gallet et al. (2003) and } \\
\text { Sauvant et al. (2004) }\end{array}$ & \\
\hline
\end{tabular}

${ }^{\text {a}}$ Weighed standard deviation (stdev) based on the numbers of samples from the sources. Values from Sauvant et al. (2004) were treated as one sample

${ }^{\mathrm{b}} \mathrm{SD}$ provided by the reference

${ }^{\mathrm{c}}$ Average stdev calculated from the stdv of the crops considered

Formula for the weighted mean $\bar{x}=\frac{\sum_{i=1}^{n} w_{i} x_{i}}{\sum_{i=1}^{n} w_{i}}$

$\mathrm{w}=$ number of observations as weights, $\mathrm{x}=$ value of observation, $\bar{x}=$ weighted average.

For these weighted averages, the standard deviations are also weighed based on the formula:

Formula for the weighted standard deviation $s d_{w}$

$$
=\sqrt{\frac{\sum_{i=1}^{n}\left(x_{i}-\bar{x}_{w}\right)^{2}}{\frac{\left(N^{\prime}-1\right) \sum_{i=1}^{n} w_{i}}{N^{\prime}}}}
$$

$\mathrm{w}=$ number of observations as weights, $\mathrm{x}=$ value of observation, $\bar{x}=$ weighted average, $\mathrm{N}^{\prime}=$ number of non-zero observations.

The $\mathrm{P}$ concentrations (\%) on dry matter vary from high values as oilseeds (ca. $0.58-0.70 \%$ ) to lower ones as in fruits $(0.07 \%)$ or fodder crops $(0.21 \%)$.

\subsection{Modelling $P$ removal with crop residues}

Crop residue is defined as the non-edible plant parts that are left in the field after harvest (Lal 2005). Crop residues include straw, head leaves and stems. Part of the residues remain in agricultural field enhancing soil organic carbon (Lugato et al. 2014) and protecting against soil erosion (Borrelli and Panagos 2020). Part of the crop residues are removed from the field for livestock feeding or bioenergy production (Scarlat et al. 2010). The removal of crop residues contributes to $\mathrm{P}$ uptake from soils (Erinle et al., 2018), but this is rarely taken into account when estimating the $\mathrm{P}$ budget (Damon et al. 2014). The $\mathrm{P}$ uptake with crop residues removal was calculated as:

P_Res $($ Tonnes $)=\operatorname{Rres} \times(\mathrm{Cpr} \times$ AUA $) \times(1-$ Hum $) \times$ Rrem $\times$ Pcr

where. 
- Rres is the ratio of residue production per tonne of crop production

- Rrem is the ratio of residues removal from the field

- Pcr is the $\mathrm{P}$ concentration of residues (\%)

- Cpr is the crop production ( $\mathrm{t} \mathrm{ha}^{-1}$ as fresh matter)

- AUA is the Agricultural utilized area (ha)

- Hum is the Humidity rate (\%)

The ratio of residue production per tonne of crop production (Rres) (Table 2) is derived from experimental sites and works (García-Condado et al. 2019; Scarlat et al. 2010) and it shows a high variation between crops (Table 2). The Rres was also compared with other literature studies (Aboudrare et al. 2006; Johnosn et al. 2006; Kadam and McMillan 2003).

Similar to other research reviews on this topic (Cherubini and Ulgiati, 2010; Scarlat et al. 2010; Kadam and McMillan 2003), we also estimated that roughly half of the annual amount of crop residues (mostly cereal straw) is removed from agricultural soils. Therefore, the ratio of residues removal from agricultural fields is around $50 \%$ for cereals and $20 \%$ for oilseeds (with a SD of $10 \%$ for both). We also assumed that the mean P concentration from plant residues is around $0.11 \%$ with a standard deviation of $\pm 0.4 \%$.

\subsection{Uncertainty}

The estimated $\mathrm{P}$ crop removal has uncertainty due to the variability in crop production, humidity rates, and the $\mathrm{P}$ concentration of plant tissues. The SD of P uptake (Table 1), the variability in humidity $( \pm 10 \%)$ (Supplementary material, Table S1), and the standard deviation in crop production, obtained from time-series statistics, were used as inputs for the uncertainty analysis.

We ran Monte-Carlo simulations (1000 drawings) within region and crop type to estimate the standard deviation for $\mathrm{P}$ crop uptake. As Monte-Carlo is an important method for uncertainty analysis, this serves to put some confidence in the output results (Janssen 2013).

The Monte-Carlo analysis estimated the uncertainty of plant harvesting based on the following probability density functions (SD stands for standard deviation of each parameter):

$$
\begin{aligned}
\text { Uncertainty }= & \text { rnorm }\left(\mathrm{n}, \mathrm{Cpr}, \mathrm{SD} \_\mathrm{Cpr}\right) \\
& \times \operatorname{rnorm}\left(\mathrm{n}, \mathrm{Pc}, \mathrm{SD} \_\mathrm{Pc}\right) \\
& \times \operatorname{rnorm}\left(\mathrm{n}, 1-\mathrm{Hum}, \mathrm{SD} \_1-\mathrm{Hum}\right) \\
& \times \text { rnorm }(\mathrm{n}, \text { Area }, \text { Area } \times 0.1)
\end{aligned}
$$

\section{Results}

\subsection{Crop production in the EU}

The crop production in the European Union (EU) and the UK in 2016 added up to approximately $300 \mathrm{Mt}$ of cereals cultivated in 57 Mha (mean $5.3 \mathrm{t} \mathrm{ha}^{-1}$ ), 33 Mt oilseeds cultivated in $12.5 \mathrm{Mha}$ (mean $2.6 \mathrm{t} \mathrm{ha}^{-1}$ ), $185 \mathrm{Mt}$ of other arable crops, $93 \mathrm{Mt}$ of vegetables cultivated in $2.6 \mathrm{Mha}, 665 \mathrm{Mt}$ of fodder crops (mean $31.4 \mathrm{t} \mathrm{ha}^{-1}$ ), $70 \mathrm{Mt}$ of fruits (mean $6 \mathrm{t}$ $\mathrm{ha}^{-1}$ ) and 1,280 Mt of grass production (Figs. 2, 3).

In the EU and the UK, $80 \%$ of the area where cereals are grown is covered by soft wheat, barley, and grain maize (Fig. 3), with total production of $140 \mathrm{Mt}, 60 \mathrm{Mt}$ and $62 \mathrm{Mt}$, respectively. Potatoes and sugar beets (category
Table 2 Ratios of residue production and residue removal used for calculating P removal with crop residues

\begin{tabular}{llll}
\hline & $\begin{array}{l}\text { Ratio of residue production per } \\
\text { tonne of crop production (Rres) }\end{array}$ & $\begin{array}{l}\text { Ratio of residues removal } \\
\text { from the field (Rrem) }\end{array}$ & $\begin{array}{l}\text { \% P on dry matter } \\
\text { of residues (Pcr) }\end{array}$ \\
\hline Cereals & & & \\
Soft wheat & 0.96 & 0.5 & 0.11 \\
Durum wheat & 0.96 & 0.5 & 0.11 \\
Rye and meslin & 1.13 & 0.5 & 0.11 \\
Barley & 0.94 & 0.5 & 0.11 \\
Oats & 1.08 & 0.5 & 0.11 \\
Grain maize & 0.99 & 0.5 & 0.11 \\
Other cereals & 0.96 & 0.5 & 0.11 \\
Paddy rice & 1.52 & 0.5 & 0.11 \\
Oilseeds & & & \\
Rape & 1.74 & 0.2 & 0.11 \\
Sunflower & 2.47 & 0.2 & 0.11 \\
Soya & 1 & 0.2 & 0.11 \\
\hline
\end{tabular}

Other outputs such as the soil loss by water and wind erosion are not yet taken into account in this study 


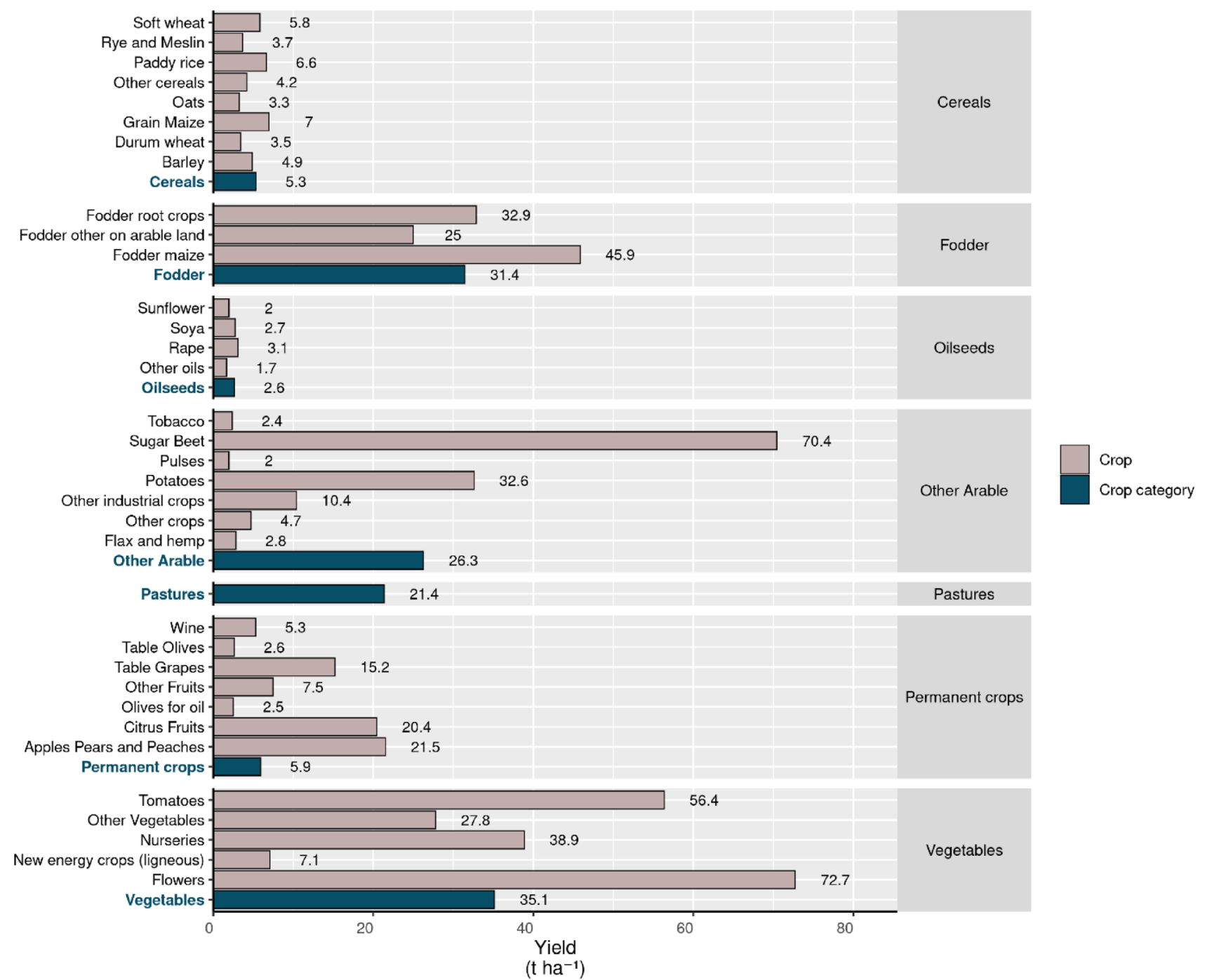

Fig. 2 Mean annual crop productivity ( $\mathrm{t} \mathrm{ha}^{-1}$ as standard humidity) for major crop categories (cereals, fodder, other arable, oilseeds, permanent crops, vegetables and pastures) and the main crops in the EU and the UK

"other arable") are harvested on 3 Mha (Fig. 3). The EU and the UK produced $120 \mathrm{Mt}$ of sugar beets (mean 70 $\mathrm{t} \mathrm{ha}^{-1}$ ), and $53 \mathrm{Mt}$ of potatoes (mean $32 \mathrm{tha}^{-1}$ ). More than half of the oilseed category is represented by rape (Fig. 3) with a production of ca. $21 \mathrm{Mt}$, followed by sunflowers (9 Mt). As for fruits, we estimate a production of $38 \mathrm{Mt}$ (pome fruit $12 \mathrm{Mt}$; citrus $11 \mathrm{Mt}$ ). In addition, the EU produced ca. $18 \mathrm{Mt}$ and $13 \mathrm{Mt}$ of grapes and olives, respectively. Among the vegetables, tomatoes harvest add up to approximately $16 \mathrm{Mt}$.

\subsection{Phosphorus removal with crop harvesting}

At the global scale, the $\mathrm{P}$ input from inorganic fertilizers is estimated at $14.2 \mathrm{Mt} \mathrm{year}^{-1}$, the $\mathrm{P}$ input from manure is about 9.6 Mt, while the P removal from harvested crops is about 12.3 Mt year ${ }^{-1}$ (MacDonald et al. 2011). In the EU and the UK, the total P removed with harvested crops is about $2.4 \mathrm{Mt}$ year $^{-1}$ with an uncertainty of $\pm 8.8 \%$ at a $90 \%$ confidence level. The quantity of $\mathrm{P}$ removed with harvesting crops varies in the range of 2.19-2.6 Mt. The mean removal with crop harvesting is about $14 \mathrm{~kg} \mathrm{P} \mathrm{ha}^{-1}$ year $^{-1}$ with an uncertainty of $1.2 \mathrm{~kg} \mathrm{P} \mathrm{ha}^{-1}$ year $^{-1}$. The $\mathrm{P}$ removal per region or country depends mainly on the amount of agricultural land, crop productivity, and crop composition.

In absolute terms, the three countries with the highest agricultural production (Germany, France, and the UK) cover ca. $1 / 3$ of the 180 Mha of agricultural lands, while their $\mathrm{P}$ plant removal is $47 \%$ of the total (ca. $1.11 \mathrm{Mt}$ of $\mathrm{P}$ ). 


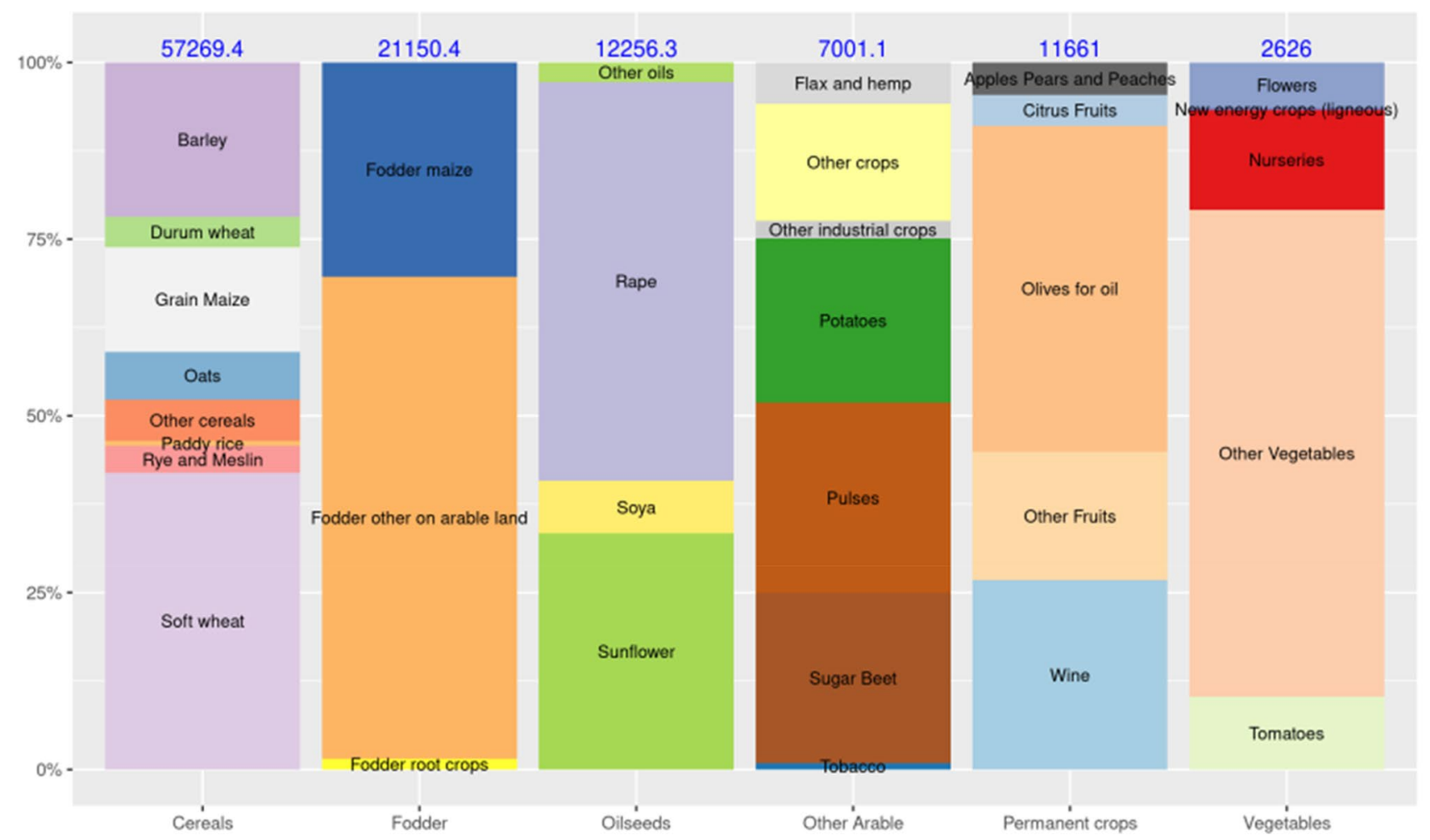

Fig. 3 Area shares (\%) per each crop in major crop categories (cereals, fodder, oilseeds, other, permanent crops, vegetables). The figures on the top represent the cultivated/harvesting area (1000 ha)

On the contrary, the larger Mediterranean countries (Spain, Italy, Portugal, and Greece) occupy $1 / 4$ of the total agricultural land but have a P removal of just around. $15 \%$ of the total. As a result of differences in both crop productivity and crop composition, the $\mathrm{P}$ removal has a high variability per country (Fig. 4) and region (Supplementary material, Fig. S1). Ireland, the Netherlands, Belgium and Denmark have the highest mean $\mathrm{P}$ removal with crop harvesting (>19 kg $\mathrm{P} \mathrm{ha}^{-1}$ year $\left.^{-1}\right)$ while the Mediterranean countries have the lowest one $\left(<10.5 \mathrm{~kg} \mathrm{P} \mathrm{ha}^{-1}\right.$ year $\left.^{-1}\right)$ (Fig. 4).

The mean $\mathrm{P}$ removal by crop harvesting is $16 \mathrm{~kg} \mathrm{ha}^{-1}$ year $^{-1}$ in cereals, $15.2 \mathrm{~kg} \mathrm{ha}^{-1}$ year $^{-1}$ in oilseeds, $38 \mathrm{~kg} \mathrm{ha}^{-1}$ year $^{-1}$ in vegetables, $13 \mathrm{~kg} \mathrm{ha}^{-1}$ year $^{-1}$ in fodder crops and pastures, and $2 \mathrm{~kg} \mathrm{ha}^{-1}$ in fruits (Fig. 5). Those values may vary per region and country as well as among the corresponding crops categories. For instance, in case of cereals, the soft wheat $\mathrm{P}$ removal is $18 \mathrm{~kg} \mathrm{ha}^{-1}$ year $^{-1}$, while rye removes only $11 \mathrm{~kg} \mathrm{ha}^{-1}$ year $^{-1}$. As for oilseeds, the $\mathrm{P}$ removal of rape is $18.9 \mathrm{~kg} \mathrm{ha}^{-1}$ year $^{-1}$ compared to $10 \mathrm{~kg} \mathrm{ha}^{-1}$ year $^{-1}$ for sunflowers. The root crops have also a high P uptake. Sugar beets, for example, remove $25 \mathrm{~kg} \mathrm{ha}^{-1}$ year $^{-1}$ and potatoes $15.7 \mathrm{~kg} \mathrm{ha}^{-1}$ year $^{-1}$. In the fruits category, pomes (apples, peaches, etc.), harvest is removing ca. $7.5 \mathrm{~kg} \mathrm{ha}^{-1}$ year $^{-1}$, the citrus $8 \mathrm{~kg} \mathrm{ha}^{-1} \mathrm{year}^{-1}$, while olive groves and vineyards have much lower $\mathrm{P}$ rates $\left(2 \mathrm{~kg} \mathrm{ha}^{-1}\right.$ year $\left.^{-1}\right)$. The boxplots represent the standard deviation of P removal per crop (Fig. 5).

Of the $2.4 \mathrm{Mt}$ of $\mathrm{P}$ removal by crop harvesting, cereals contribute the major part (38\%), followed by pastures (33\%), and fodder crops (12\%) (Fig. 4). Fruit trees, vegetables, oilseeds, and other arable crops contribute $1 \%, 4 \%, 8 \%$ and $4 \%$ of total P removal, respectively. In most crop categories (pastures, fodder crops, other arable and oilseeds), the total $\mathrm{P}$ removal is analogous to the share of agricultural land. For example, pastures occupy $33 \%$ of agricultural land and contribute to $33 \%$ of P removal. However, fruits occupy around $6.5 \%$ of the total agricultural area and have a low share of $\mathrm{P}$ removal (1\%) due to their low dry matter content (Fig. 4 and Fig. 5). On the contrary, the vegetables occupy only $1.4 \%$ of the agricultural land and contribute $4 \%$ of $\mathrm{P}$ removal. The cereals are cultivated in $31.7 \%$ of the EU and the UK and contribute to $38 \%$ of total P removal with harvesting (Fig. 5).

The share of each crop category in uptake removal shows high variability (Fig. 4). While the fruits have an overall $1 \%$ share of the EU agricultural area, most of the Mediterranean countries (Cyprus, Greece, Spain, and Italy) have more than $5 \%$ of total P removed by fruits (Fig. 4a). Pastures contribute to most of the $\mathrm{P}$ exportation in Ireland (80\%), Slovenia (60\%), and the UK (59\%). Vegetables have a substantial P removal share in the Netherlands (20\%), Malta, Italy and Portugal. 

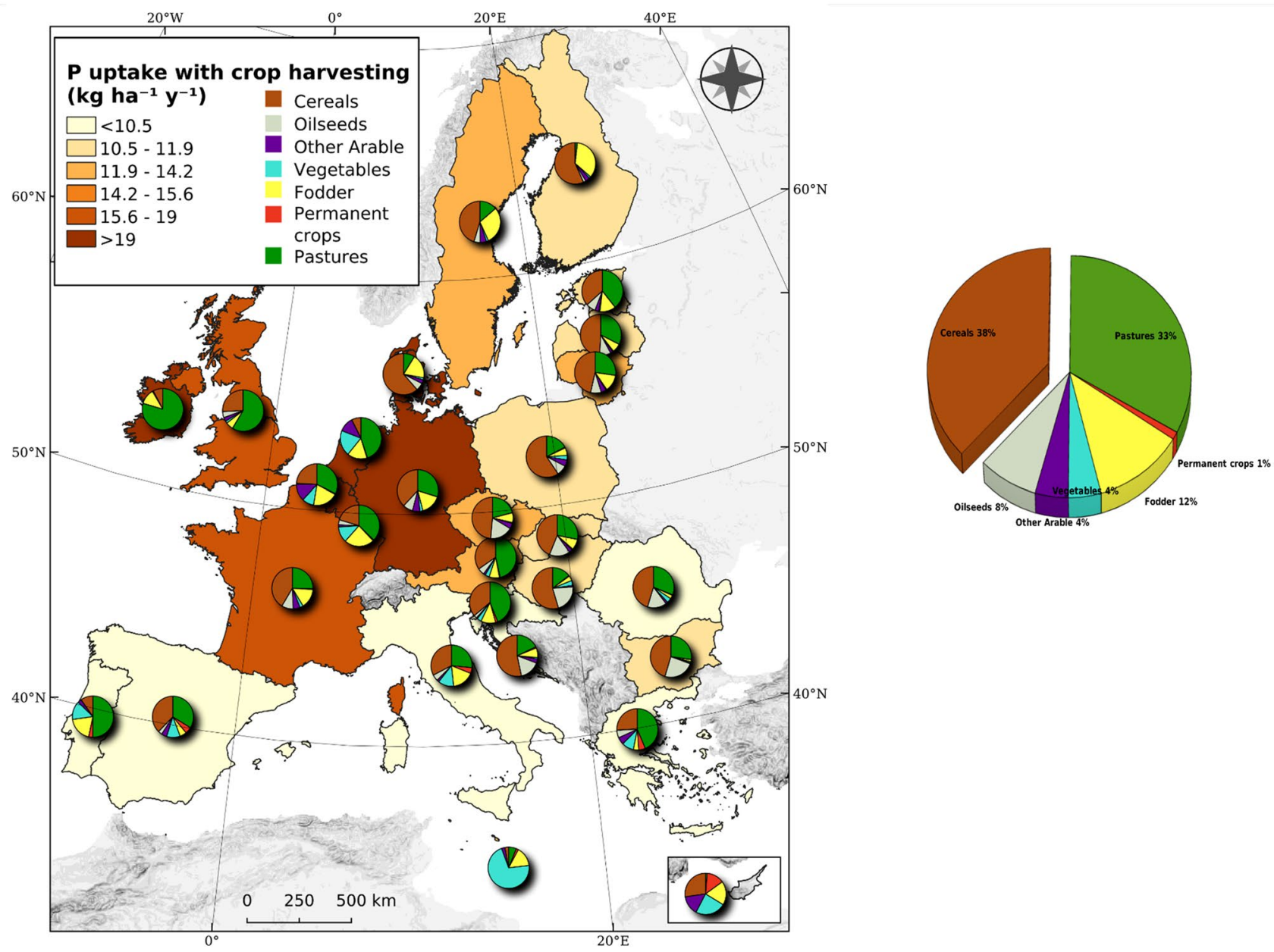

Fig. 4 The mean P removal by crop harvesting per country $\left(\mathrm{kg} \mathrm{ha}^{-1}\right)$. The pies are showing the share of the P exportation per crop category for each country (left) and per crop category for the whole study area (right)

\subsection{Phosphorus removal with crop residues}

The total crop residues produced from agricultural lands are estimated to be about $353 \mathrm{Mt}(\max .395 \mathrm{Mt})$ with the cereals producing the major part of it (ca. $292 \mathrm{Mt} \pm 25 \mathrm{Mt}$ ). The results show that $130 \mathrm{Mt}$ of dry matter crop residues per year are removed each year in the EU27 and UK.

The total P removal by crop residues is about $151,000 \mathrm{t}$ with $\pm 14 \%$ uncertainty at a $90 \%$ confidence level. In regions and countries where cereals have the highest contribution to the agricultural production, $P$ removal by plant residues was above $1 \mathrm{~kg} \mathrm{ha}^{-1}$ year $^{-1}$ (Fig. 6). Around $78 \%$ of P removal with crop residues is due to the three main cereals cultivated in the EU (soft wheat, barley, grain maize). Those percentages are in agreement with studies of crop residues availability in the EU (Scarlat et al. 2010). In absolute terms, France has the largest amount of $\mathrm{P}$ removal by crop residues (ca. 30 kt), followed by Germany (20 kt), Poland, Spain, and Romania (brown bars in Fig. 7).

\section{Discussion}

By summing up the $\mathrm{P}$ removal with crop harvesting and residues, we estimate a total $\mathrm{P}$ uptake of $2.55 \mathrm{Mt}$ with an uncertainty of $\pm 0.23 \mathrm{Mt}$. Most of the North-West EU regions (North France, Ireland, Belgium, Germany, Netherlands and Denmark) have a mean P removal higher than $22 \mathrm{~kg} \mathrm{ha}^{-1}$ year $^{-1}$ (Fig. 7). In Mediterranean countries this rate is less than $11 \mathrm{~kg} \mathrm{ha}^{-1}$ year $^{-1}$ while the Eastern EU countries have rates in the range of 13-17 kg ha ${ }^{-1}$ year $^{-1}$. Detailed data per country are available in the Supplementary material (Table S2).

At the EU level, the $\mathrm{P}$ removal with residues is about $6.3 \%$ of that of crop harvesting. As the P removal with crop residues is higher in agricultural lands with a higher share of cereals, Poland, Hungary, Romania, and Bulgaria remove more than $10 \%$ of total $\mathrm{P}$ by crop residues (Fig. 7). 


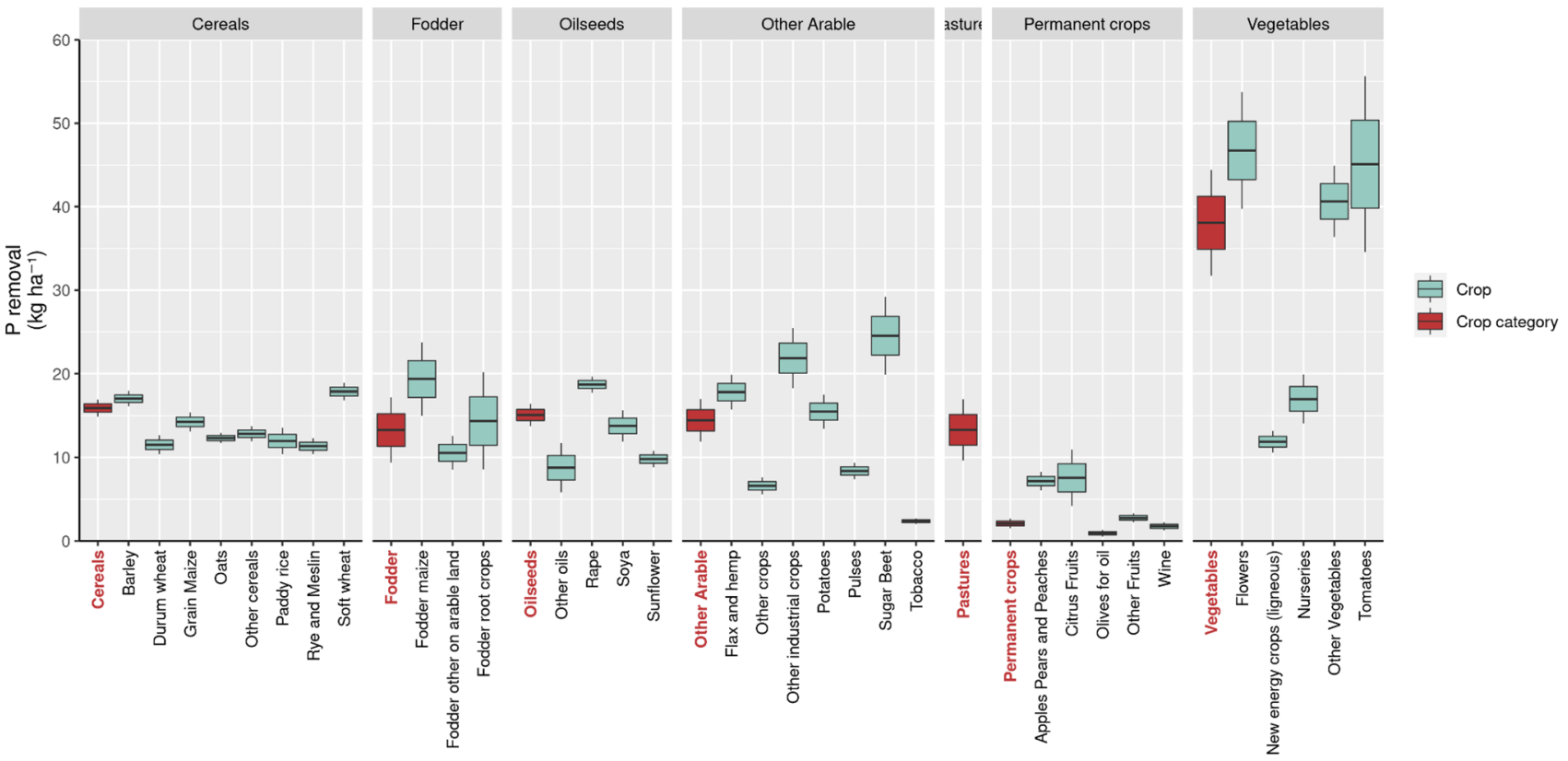

Fig. 5 Mean P removal due to crop harvesting $\left(\mathrm{kg} \mathrm{ha}^{-1}\right)$ for major crop categories (cereals, fodder, other arable, oilseeds, permanent crops, vegetables, and pastures) and the main crops. The boxplots represent the range of values $( \pm \operatorname{stdev})$

The 2.55 Mt of P exportation by crop harvesting gives a useful indication of the amount of $\mathrm{P}$ that should be added through fertilizer (organic/inorganic) per year. However, this may not be the case as suggested by the different $\mathrm{P}$ availability in EU agricultural soils (Fig. 1). Therefore, a detailed input/output $\mathrm{P}$ budget is necessary for sustainable nutrient management and policy recommendation. In such decisions, both farmers and policy makers should take into account $\mathrm{P}$ outputs by crop harvesting, also in combination with the $\mathrm{P}$ availability in topsoils (Ballabio et al. 2019) and phosphorus fertilization needs in each region (Tóth et al. 2014). Therefore, $\mathrm{P}$ fertilizers could be reduced under optimal values on saturated agricultural fields to avoid $\mathrm{P}$ losses to the environment (Garske et al. 2020). On the opposite, P fertilization could be increased under soil mining condition and lower $\mathrm{P}$ availability. This is useful from both an economic and an ecological point of view.

This is the first attempt to estimate P removal by crops and residues at European scale using detailed crop production data for 37 crops at a regional scale (220 regions). This will contribute to compile the $\mathrm{P}$ budget at the European scale and identify $\mathrm{P}$ surplus or deficit areas. Therefore, it is important to have a conservative nutrient management plan in areas with $\mathrm{P}$ surplus and implement a more efficient fertilizer and manure use in areas with $\mathrm{P}$ deficit. However, the policy interventions should also address the targets at farm scale depending on soil quality and the status of soil physical and chemical properties of the agricultural field.
The estimate of total P removed from soils does not yet include the losses by water erosion. It is known that the mean soil loss due to water erosion in the EU is about 2.45 $\mathrm{t} \mathrm{ha}^{-1}$ year $^{-1}$ (Panagos et al. 2020), with agricultural soils having higher losses at $3 \mathrm{t} \mathrm{ha}^{-1}$ year $^{-1}$. Integrating soil erosion into the $\mathrm{P}$ budget framework will be addressed in a future research targeting the whole P budget. In a recent global assessment done at coarse resolution, the $\mathrm{P}$ removed through soil erosion in Europe is estimated to be about $1 \mathrm{~kg} \mathrm{ha}^{-1}$ year $^{-1}$ (Alewell et al. 2020).

In addition, we aim at providing a data management platform for $\mathrm{P}$ budget on a regular basis. Our plan is to provide annual updates based on updated crop production and fertilizer consumptions statistics in the EU. This would allow monitoring the nutrient uptake and the sustainable use of fertilizers in accordance with the EU Green Deal policy targets. In addition, as the CAPRI model includes a trend projection module for future agriculture production and commodity markets, future trends in land use and cropping systems can be assessed (Himics et al. 2018; Wirzke et al. 2012).

The land occupied per each cropping system and the productivity trends for 2030 estimated by CAPRI is shown in Fig. 8. In 2030, the agricultural land in EU-27 and UK will be 168.4 Mha, which is $1.7 \%$ less compared to the 2016 baseline mainly due to cereals and oilseeds reduction. Areas for fodder crops and pastures will remain rather stable. According to CAPRI, the area of cereals will be reduced by $0.5 \mathrm{Mha}$ $(-1 \%)$ followed by a reduction in pastures and permanent crops (Fig. 8). However according to the CAPRI projections, 


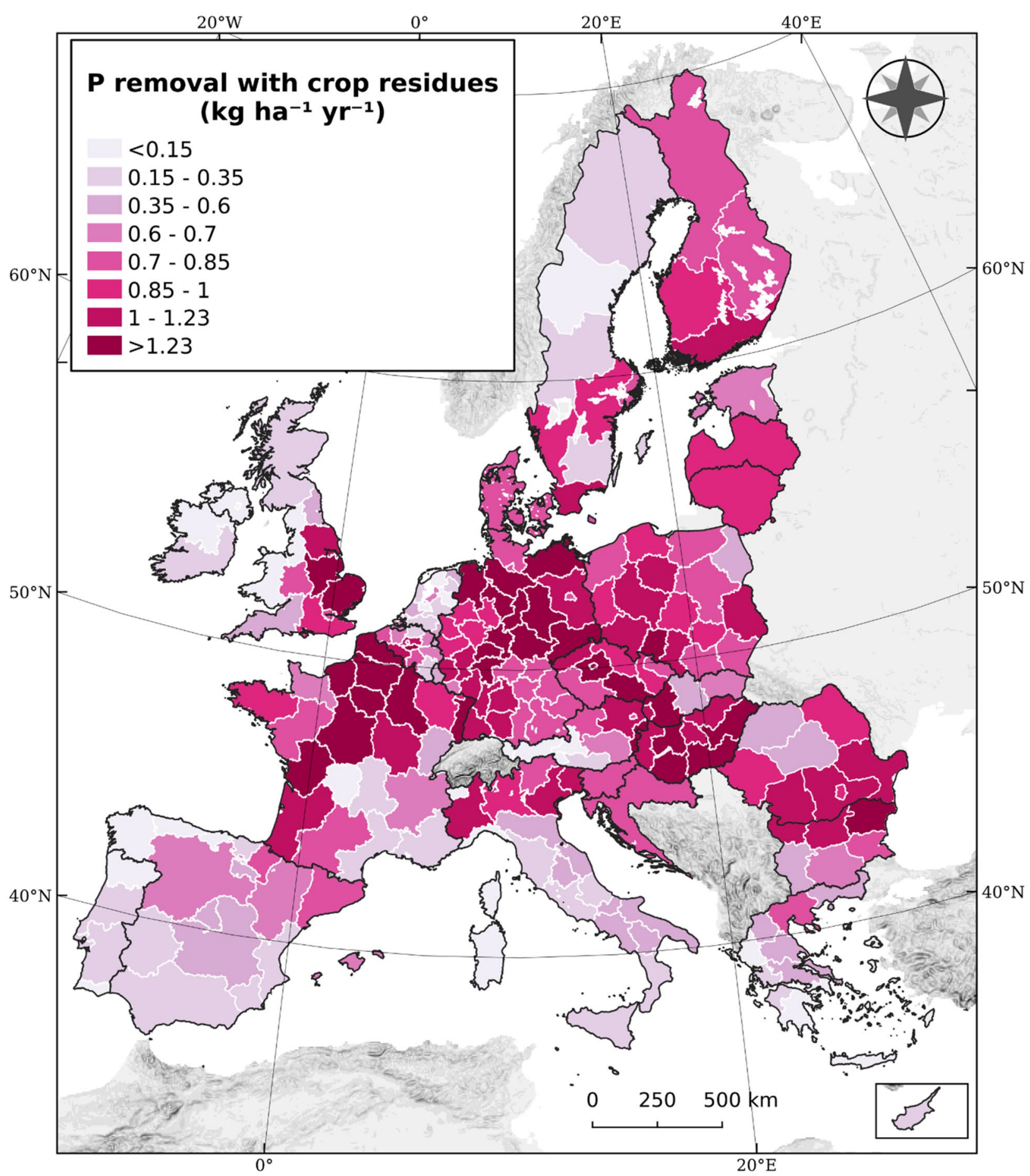

Fig. 6 Phosphorus removal $\left(\mathrm{kg} \mathrm{ha}^{-1}\right.$ year $\left.^{-1}\right)$ by crop residues at the regional scale

the productivity rates will be higher resulting in higher crop production. For example, the cereal production may reach 325 $\mathrm{Mt}$, in line with the projections of the EU Agricultural outlook 2018. In the oilseeds category, the rapeseed will show a decline, while the soya and sunflower an increasing trend.
As the production of crops will be higher in 2030 (compared to 2016), the $\mathrm{P}$ removal with crop harvesting is expected to increase by $4 \%$ (Fig. 8), totaling circa 2.52 Mt in 2030 (compared to $2.4 \mathrm{Mt}$ in 2016). Therefore, it is important to take into account the implications of land use changes, crop systems changes and productivity increases in 


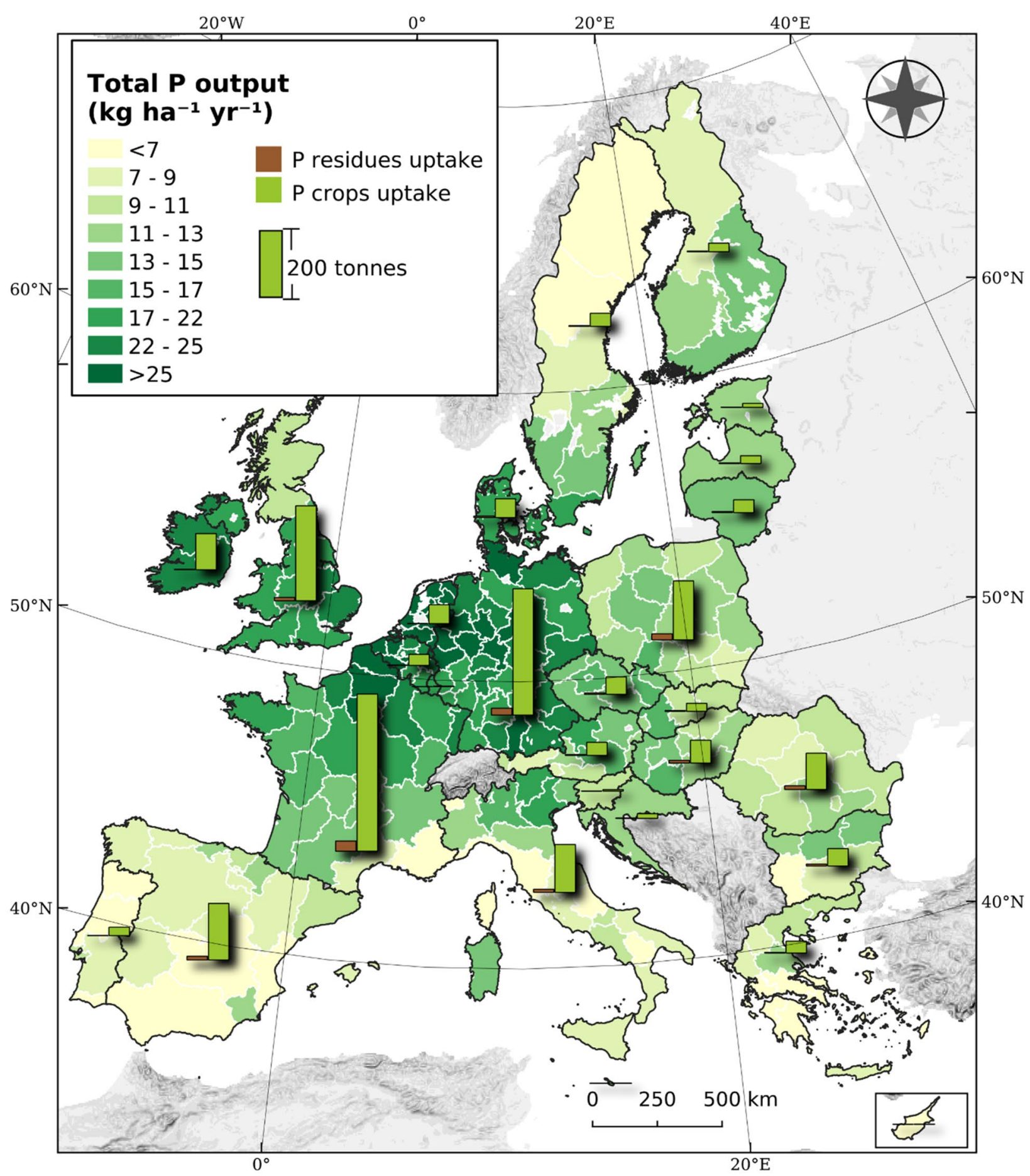

Fig. 7 Total phosphorus removal per country and region. Green bars aggregate $\mathrm{P}$ crop removal per country and brown ones are the aggregated $\mathrm{P}$ removal with residues (Color figure online)

the medium-term future (2030) under the F2F Strategy. In addition, it is important to further investigate how the ambitious environmental objectives of the F2F Strategy can be reached in a competitive global trade system which projects increase in food and feed requirements.
The data, maps, and the model implementation for $\mathrm{P}$ removal will be available in the European Soil Data Centre (ESDAC) (Panagos et al. 2012). 


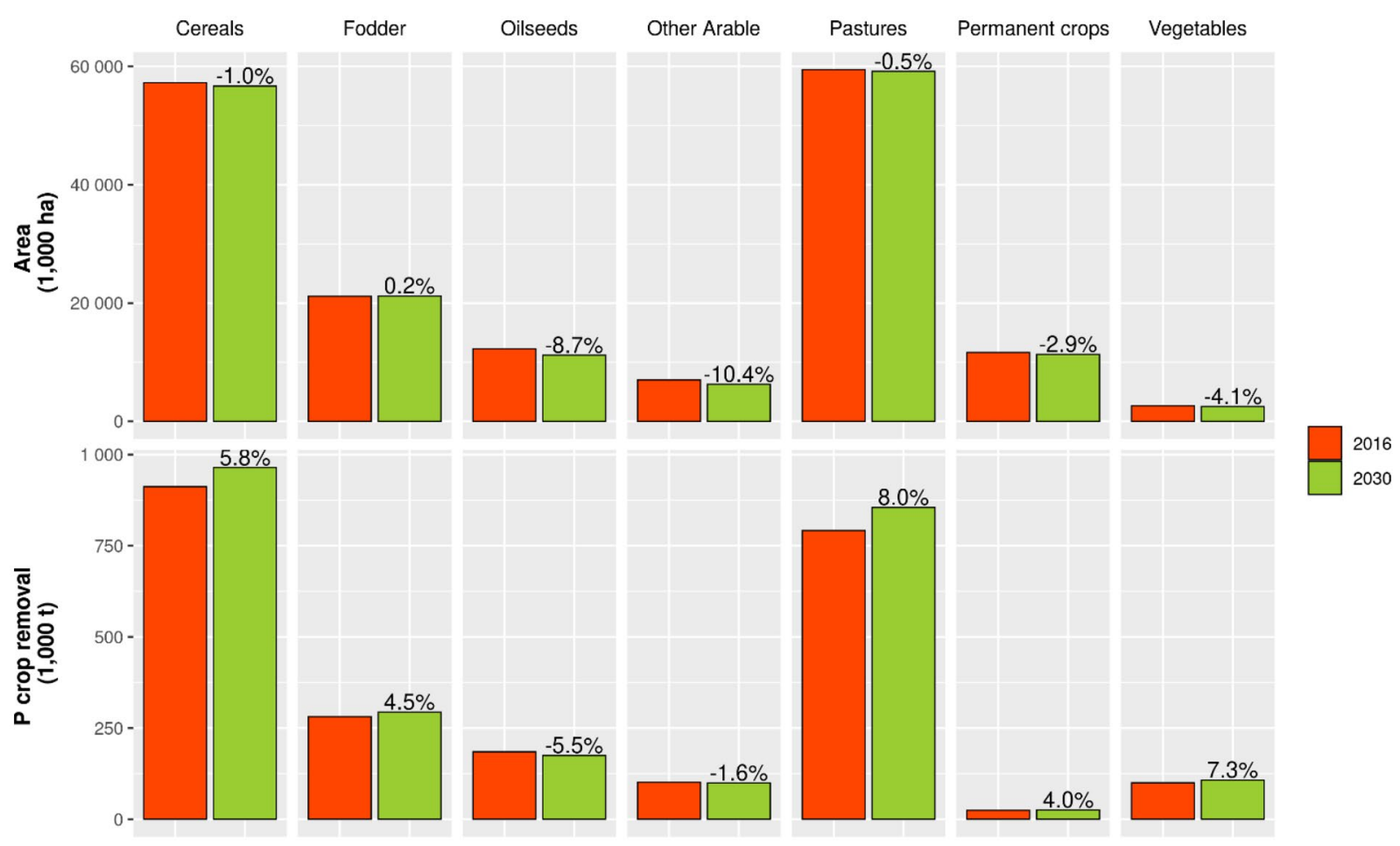

Fig. 8 Projections of crop area changes in 2030 (top) and scenarios for future P removal with crop harvesting (bottom)

\section{Conclusions}

The P removal from agricultural lands in the EU and UK (ca. 170 Mha) by crop harvesting and residues is about 2.55 Mt with an uncertainty of $\pm 9 \%$. Based on the P budget data framework that we built, we estimated $\mathrm{P}$ removal per country, region, and each of the 37 crops cultivated.

Mean $\mathrm{P}$ removal by crop harvesting is $14 \mathrm{~kg} \mathrm{ha}^{-1}$ year $^{-1}$, with cereals and vegetables having higher rates, while fruits having much lower ones. In most of the North-western European regions, the rates of $\mathrm{P}$ removal are higher than $20 \mathrm{~kg} \mathrm{ha}^{-1}$ year ${ }^{-1}$, while rates are lower than $10 \mathrm{~kg} \mathrm{ha}^{-1}$ in Mediterranean regions and South-East EU countries. The crop residues represent a small proportion of the total $\mathrm{P}$ output (ca. $6 \%$ ), while areas cultivating cereals contribute the most.

Due to the high costs of P fertilizers, limited availability and potential risk of diffuse contamination, the knowledge of $P$ removal and its use by crop plants is essential for the best management of this essential nutrient. The outputs of the $P$ budget data framework may contribute to improve the current indicators on $\mathrm{P}$ balance at regional and European scale.

Scenarios of agricultural production in 2030 estimate an increase in $\mathrm{P}$ removal at $4 \%$. Therefore, the investigation on how the increased agricultural productivity (and hence $\mathrm{P}$ demand) projected for 2030 will affect the policy targets of F2F Strategy is necessary.
Supplementary Information The online version contains supplementary material available at https://doi.org/10.1007/s00003-022-01363-3.

Acknowledgements Administrative Arrangement Integrated Nutrient Management Action Plan (INMAP) No c.35914 between JRC and DG ENV.

\section{Declarations}

Conflict of interest The authors declare that they have no conflict of interest.

Open Access This article is licensed under a Creative Commons Attribution 4.0 International License, which permits use, sharing, adaptation, distribution and reproduction in any medium or format, as long as you give appropriate credit to the original author(s) and the source, provide a link to the Creative Commons licence, and indicate if changes were made. The images or other third party material in this article are included in the article's Creative Commons licence, unless indicated otherwise in a credit line to the material. If material is not included in the article's Creative Commons licence and your intended use is not permitted by statutory regulation or exceeds the permitted use, you will need to obtain permission directly from the copyright holder. To view a copy of this licence, visit http://creativecommons.org/licenses/by/4.0/.

\section{References}

Aboudrare A, Debaeke P, Bouaziz A, Chekli H (2006) Effects of soil tillage and fallow management on soil water storage and sunflower 
production in a semi-arid Mediterranean climate. Agric Water Manag 83(3):183-196

Alewell C, Ringeval B, Ballabio C et al (2020) Global phosphorus shortage will be aggravated by soil erosion. Nat Commun 11:1-12

Almeida RF, Queiroz IDS, Mikhael JER et al (2019) Enriched animal manure as a source of phosphorus in sustainable agriculture. Int J Recycl Org Waste Agric 8:203-210

Antikainen R, Haapanen R, Lemola R et al (2008) Nitrogen and phosphorus flows in the Finnish agricultural and forest sectors, 1910 2000. Water Air Soil Pollut 194:163-177

Bai Z, Li H, Yang X, Zhou B, Shi X, Wang B, Li D, Shen J, Chen Q, Qin W, Oenema O (2013) The critical soil P levels for crop yield, soil fertility and environmental safety in different soil types. Plant Soil 372(1):27-37

Ballabio C, Lugato E, Fernández-Ugalde O et al (2019) Mapping LUCAS topsoil chemical properties at European scale using Gaussian process regression. Geoderma 355:113912

Beckman J, Ivanic M, Jelliffe J (2021) Market impacts of farm to fork: reducing agricultural input usage. Appl Econ Perspect Policy

Biavetti I, Karetsos S, Ceglar A et al. (2014) European meteorological data: contribution to research, development, and policy support. In: Second international conference on remote sensing and geoinformation of the environment (RSCy2014). International Society for Optics and Photonics, p 922907

Blake L, Mercik S, Koerschens M et al (2000) Phosphorus content in soil, uptake by plants and balance in three European long-term field experiments. Nutr Cycl Agroecosyst 56:263-275

Borrelli P, Panagos P (2020) An indicator to reflect the mitigating effect of common agricultural policy on soil erosion. Land Use Policy 92:104467

Bouwman L, Goldewijk KK, Van Der Hoek KW et al (2013) Exploring global changes in nitrogen and phosphorus cycles in agriculture induced by livestock production over the $1900-2050$ period. Proc Natl Acad Sci 110:20882-20887

Broadley MR, Bowen HC, Cotterill HL et al (2004) Phylogenetic variation in the shoot mineral concentration of angiosperms. J Exp Bot 55:321-336

Carpenter SR (2008) Phosphorus control is critical to mitigating eutrophication. Proc Natl Acad Sci 105:11039-11040

Carpenter SR, Bennett EM (2011) Reconsideration of the planetary boundary for phosphorus. Environ Res Lett 6(1):014009

Cherubini F, Ulgiati S (2010) Crop residues as raw materials for biorefinery systems - a LCA case study. Appl Energy 87(1):47-57

Damon PM, Bowden B, Rose T, Rengel Z (2014) Crop residue contributions to phosphorus pools in agricultural soils: a review. Soil Biol Biochem 74:127-137

Dawson CJ, Hilton J (2011) Fertiliser availability in a resource-limited world: production and recycling of nitrogen and phosphorus. Food Policy 36:S14-S22

Du Preez CC, van Huyssteen CW, Kotzé E, van Tol JJ (2020) Ecosystem services in sustainable food systems: operational definition, concepts, and applications. In: The role of ecosystem services in sustainable food systems. Elsevier, pp 17-42

Dupas R, Delmas M, Dorioz J-M et al (2015) Assessing the impact of agricultural pressures on $\mathrm{N}$ and $\mathrm{P}$ loads and eutrophication risk. Ecol Ind 48:396-407

Ehlert PA, Dekker PH, van der Schoot JR, Visschers R, van Middelkoop JC, van der Maas MP, Pronk AA, van Dam AM (2009) Fosforgehalten en fosfaatafvoercijfers van landbouwgewassen: eindrapportage. Alterra

Erinle KO, Li J, Doolette A, Marschner P (2018) Soil phosphorus pools in the detritusphere of plant residues with different $\mathrm{C} / \mathrm{P}$ ratioinfluence of drying and rewetting. Biol Fertil Soils 54:841-852

European Commission (2020) A farm to fork strategy for a fair, healthy and environmentally-friendly food system. https://ec.europa.eu/ food/horizontal-topics/farm-fork-strategy_en. Accessed 5 Jan 2022

Eurostat (2020a) Annual crop statistics. https://ec.europa.eu/eurostat/ databrowser/view/apro_cpsh1/default/table?lang=en. Accessed 15 July 2021

Fageria NK, Moreira A, Dos Santos AB (2013) Phosphorus uptake and use efficiency in field crops. J Plant Nutr 36:2013-2022

Fischer P, Pöthig R, Venohr M (2017) The degree of phosphorus saturation of agricultural soils in Germany: current and future risk of diffuse P loss and implications for soil P management in Europe. Sci Total Environ 599:1130-1339

Gallet A, Flisch R, Ryser J-P et al (2003) Effect of phosphate fertilization on crop yield and soil phosphorus status. J Plant Nutr Soil Sci 166:568-578

García-Condado S, López-Lozano R, Panarello L et al (2019) Assessing lignocellulosic biomass production from crop residues in the European Union: modelling, analysis of the current scenario and drivers of interannual variability. GCB Bioenergy 11:809-831

Garske B, Stubenrauch J, Ekardt F (2020) Sustainable phosphorus management in European agricultural and environmental law. Rev Eur Comp Int Environ Law 29(1):107-117

Giardini L (2002) Agronomia generale. Patron. Bologna, Italy

Himics M, Fellmann T, Barreiro-Hurlé J et al (2018) Does the current trade liberalization agenda contribute to greenhouse gas emission mitigation in agriculture? Food Policy 76:120-129

Janssen H (2013) Monte-Carlo based uncertainty analysis: sampling efficiency and sampling convergence. Reliab Eng Syst Saf 109:123-132

Johnson JF, Allmaras RR, Reicosky DC (2006) Estimating source carbon from crop residues roots and rhizodeposits using the national grain-yield database

Kadam KL, McMillan JD (2003) Availability of corn stover as a sustainable feedstock for bioethanol production. Biores Technol 88(1):17-25

Köninger J, Lugato E, Panagos P et al (2021) Manure management and soil biodiversity: towards more sustainable food systems in the EU. Agric Syst 194:103251

Lal R (2005) World crop residues production and implications of its use as a biofuel. Environ Int 31(4):575-584

Langeveld JWA, Verhagen A, Neeteson JJ et al (2007) Evaluating farm performance using agri-environmental indicators: recent experiences for nitrogen management in The Netherlands. J Environ Manag 82:363-376

Lu C, Tian H (2017) Global nitrogen and phosphorus fertilizer use for agriculture production in the past half century: shifted hot spots and nutrient imbalance. Earth Syst Sci Data 9(1):181-192

Lugato E, Bampa F, Panagos P, Montanarella L, Jones A (2014) Potential carbon sequestration of European arable soils estimated by modelling a comprehensive set of management practices. Glob Change Biol 20(11):3557-3567

MacDonald GK, Bennett EM, Potter PA, Ramankutty N (2011) Agronomic phosphorus imbalances across the world's croplands. Proc Natl Acad Sci 108:3086-3091

Moe K, Htwe AZ, Thu TTP et al (2019) Effects on NPK status, growth, dry matter and yield of rice (Oryza sativa) by organic fertilizers applied in field condition. Agriculture 9:109

Montanarella L, Panagos P (2021) The relevance of sustainable soil management within the European Green Deal. Land Use Policy 100:104950

Morari F, Lugato E, Berti A, Giardini L (2006) Long-term effects of recommended management practices on soil carbon changes and sequestration in north-eastern Italy. Soil Use Manag 22:71-81

Morari F, Lugato E, Giardini L (2008) Olsen phosphorus, exchangeable cations and salinity in two long-term experiments of north-eastern Italy and assessment of soil quality evolution. Agric Ecosyst Environ 124:85-96 
OECD (2007). OECD gross phosphorus balance. https://stats.oecd.org/ index.aspx?queryid=79765. Accessed 12 June 2021

Ohm M, Paulsen HM, Moos JH, Eichler-Löbermann B (2017) Longterm negative phosphorus budgets in organic crop rotations deplete plant-available phosphorus from soil. Agron Sustain Dev 37:1-9

Orgiazzi A, Ballabio C, Panagos P et al (2018) LUCAS Soil, the largest expandable soil dataset for Europe: a review. Eur J Soil Sci 69:140-153

Ott C, Rechberger H (2012) The European phosphorus balance. Resour Conserv Recycl 60:159-172

Palese AM, Celano G, Xiloyannis C (2012) Esigenze Minerali e tecniche di concimazione. ISSN 2281-4930. https://accademiao livoeolio.com/img2/file/palese-et-al-esigenze-minerali-e-tecni che-diconcimazione_201804061101921_9c1pcptsi5mnhw9ivqw4 d800z.pdf. Accessed 15 Sept 2021

Panagos P, Van Liedekerke M, Jones A, Montanarella L (2012) European Soil Data Centre: response to European policy support and public data requirements. Land Use Policy 29:329-338

Panagos P, Ballabio C, Yigini Y, Dunbar MB (2013) Estimating the soil organic carbon content for European NUTS2 regions based on LUCAS data collection. Sci Total Environ 442:235-246

Panagos P, Ballabio C, Poesen J et al (2020) A soil erosion indicator for supporting agricultural, environmental and climate policies in the European Union. Remote Sens 12(9):1365

Panagos P, Ballabio C, Himics M et al (2021) Projections of soil loss by water erosion in Europe by 2050. Environ Sci Policy 124:380-392

Piccoli I, Sartori F, Polese R, Borin M, Berti A (2021) Can long-term experiments predict real field $\mathrm{N}$ and $\mathrm{P}$ balance and system sustainability? Results from maize, winter wheat, and soybean trials using mineral and organic fertilisers. Agronomy 11(8):1472

Rideout JW, Gooden DT (2000) Effects of starter fertilizer granular Phosphorus fertilizer time of fertilization and seedling Phosphorus concentration on Flue-cured Tobacco growth and nutrition. Tob Sci. https://doi.org/10.3381/0082-4623-44.1.19

Roberts TL, Johnston AE (2015) Phosphorus use efficiency and management in agriculture. Resour Conserv Recycl 105:275-281
Sauvant D, Perez JM, Tran G (2004) Tables of composition and nutritional value of feed materials: pigs, poultry, cattle, sheep, goats, rabbits, horses and fish. Wageningen Academic Publishers. ISBN 2-7380-1158-6

Scarlat N, Martinov M, Dallemand J-F (2010) Assessment of the availability of agricultural crop residues in the European Union: potential and limitations for bioenergy use. Waste Manag 30:1889-1897

Schoumans OF, Bouraoui F, Kabbe C et al (2015) Phosphorus management in Europe in a changing world. Ambio 44:180-192

Sharpley AH, Beegle D, Bolster C, Good L, Joern B, Ketterings Q, Lory J, Mikkelsen R, Osmond D, Vadas P (2012) Phosphorus indices: why we need to take stock of how we are doing. J Environ Qual 41:1711-1719

Smil V (2000) Phosphorus in the environment: natural flows and human interferences. Annu Rev Energy Environ 25:53-88

Soille P, Burger A, De Marchi D et al (2018) A versatile data-intensive computing platform for information retrieval from big geospatial data. Future Gener Comput Syst 81:30-40

Tóth G, Guicharnaud R-A, Tóth B, Hermann T (2014) Phosphorus levels in croplands of the European Union with implications for P fertilizer use. Eur J Agron 55:42-52

Veneto Agricultura (2020) Nutrizione della vite. https://www.venet oagricoltura.org/upload/pubblicazioni/GUIDA_PER_IL_VITIC OLTORE/4\%20Nutrizione.pdf. Accessed 15 Oct 2021

Whalen JK, Chang C (2001) Phosphorus accumulation in cultivated soils from long-term annual applications of cattle feedlot manure. J Environ Qual 30:229-237

White PJ, Hammond JP (2008) Phosphorus nutrition of terrestrial plants. In: White PJ, Hammond JP (eds) The ecophysiology of plantphosphorus interactions, vol 7. Springer, Dordrecht, pp $51-81$

Wirzke $\mathrm{H}$ et al (2012) The CAPRI Agricultural Model. Uncertainty Treatment. EC4MACS

Publisher's Note Springer Nature remains neutral with regard to jurisdictional claims in published maps and institutional affiliations. 